\title{
Male Solitude: a reflection of the impact of silence for men
}

\author{
Rivaldo Mendes da Silva ${ }^{1 *}$; José Lamartine da Silva²; Marcelo Henrique Gonçalves de Miranda ${ }^{3}$ \\ ${ }^{1}$ Master's degree in Contemporary Education from the Federal University of Pernambuco - UFPE; Specialist in Mental Health Management at \\ Cândido Mendes University - UCAM; Bachelor of Psychology from the University Center of Vitória de Santo Antão - UNIVISA. \\ ${ }^{2}$ Bachelor of Psychology from Vale do Ipojuca University Center - UNIFAVIP. \\ ${ }^{3} \mathrm{PhD}$ in Sociology from the Federal University of Pernambuco - UFPE; Graduated in History from the Catholic University of Pernambuco. \\ Advisor. Professor at the Academic Center of Agreste - CAA of UFPE.
}

E-mail adresses: rivaldomendespsi@gmail.com (Rivaldo Mendes da Silva), lamartine1986@gmail.com. (José Lamartine da Silva), mm.marcelohenrique@yahoo.com.br (Marcelo Henrique Gonçalves de Miranda)

${ }^{*}$ Corresponding author

\section{To cite this article:}

Silva, R. M.; Silva, J. L.; Miranda, M. H. G. Male Solitude: a reflection of the impact of silence for men. International Journal of Sciences. Vol. 1, No. 1, 2021, pp. 45-50.

Received: 03 04, 2021; Accepted: 03 05, 2021; Published: 03 14, 2021

\begin{abstract}
Affection among male individuals is a social issue to be dialogued, for many years it was silenced for defending the image of a subject who does not express feelings. The reconstruction of affections in masculinity is to enable silence to be remeant to be verbalized. In order to identify the male suffering silenced by the lack of expression of affectivity, the methodology used was elaborated through a bibliographic survey in articles and books on the theme on screen, through records. The cultural production imposed of sexism by patriarchy, produces the idea that this genre does not need to understand feelings, is a matter of silence for being part of the identity of being man. When the subjects recognize the affections and experience them, it is possible to develop their potentialities by understanding their affections and enabling them to have more harmonious social relationships, through the movement of understanding their momentary limitations to develop significant changes in their development as a human being. Masculinity needs to be reflected by its built social roles, openness to affection will bring to masculinity possibilities to build the identities of men to experience the social relations free of stereotypes that will benefit their own health.
\end{abstract}

Keywords: Males; Masculinities; Silence.

\section{Introduction}

Masculinities have a rise in the 1960s and 1970s in Brazil with the actions of social movements, the feminist and lesbian, gay, bisexual and transsexual (LGBT) movement. To understand this space is to seek a social construction that involves the (re)construction of the ideals of patriarchy for this group. By involving masculinities, the social roles that heteronormative men needed to play in order to reaffirm being a man, which dominated women. Lenner (2019) reports how the system is coercive through sexual activities, economic resources and the political power of body domination. It presents the domination of masculinities as resources of affirmation of being man, as the social movements mentioned above the discussions about this category involved reflections and new ways of visualizing masculinity that went from singular to plural, masculinities.

Becoming a man is a social construct. For Mead (2001), male and female behaviors are understood by social construction and culture involvement. Since the generation the behaviors intended to be masculine are intended for their bodies, such as clothing, colors, toys, the choice of name. These cultural rules involve the determination of the sex given as biological, presenting social patterns. Banditer (1997), reports that being a man goes beyond that determined by the biological that refers to sexual organs seen as male. For the author is an identification with the expression of the genre. From an early age child, read as masculine are coercive with words to behave like men implying in the behaviors that must follow, among them being the silencing feelings, the male cannot demonstrate affection, for him it is necessary not to expose the pains and seek loneliness. The search for loneliness the man falls ill and at the mercy of this illness symptoms affect his mental health, among them anxious symptoms, depressives, compulsions, addictions; thus, moving them to a state of suffering to maintain their rank of male not to be questioned their manhood. The speech 
for masculinity is to seek its subjective care, develop its potentialities, understand its affections and move significant changes in the way of seeing the world. To allow oneself to be a freer man who seeks the freedom to be a man and not the care of how to affirm how to be a man, as determined by compulsory patriarchy. This explanation presents the objective of the research in identifying male suffering silenced by the lack of expression of affectivity.

\section{.2. Methodology}

This is a review in the literature through a bibliographic survey in articles and books on the theme on screen, through the method of records for the elaboration of the research material. We searched and analyzed works available in the research databases: Academic Google, using the following descriptors: Men, Masculinities, Mental Health of Man and Loneliness

\section{Results and Discussion}

Studies on masculinities present visibility in Brazil as traces of the feminist movement. Researchers on the subject have brought a new perspective on what it is to be a man and how contemporaneity is welcoming this new understanding. However, it is important to emphasize that in the 1960s and 1970 s, with the rise of the feminist movement and the notoriety of the LGBT movement, there was the possibility of reflecting on gender. Feminists aimed to lead women to become aware of violence, domination and exploitation by men and to fight for gender equality. Impeccably, Bell Hooks defines feminism as "[...] movement aimed at ending sexism, sexist exploitation and oppression [...]" (Hooks, 2000, p.1). Thus, "feminism appears as a reflexive reference for men who are reviewing the male condition [...]" (Nolasco, 1993, p. 20). Gomáriz (1992) denotes that it was during this period that the academic community focused attentively to masculinities. Nevertheless, we find scholars who think a little differently, these claim that only in the 1980s began research and that it was in the 90's that the great scientific productions occurred with masculinities as the object of study. Medrado and Lyra (2008, p. 809), state:

The productions on masculinities, as an object of study itself, on the other hand, began at the end of the 1980s, from works produced in a still unsystematic way, with concentration on specific authors and without necessarily unfolding in a broad and consistent theoretical, epistemological, political and ethical discussion on the subject.

Thinking about masculinities is important to understand history from a sociological, anthropological, religious and political perspective. In view of these perspectives, pointing to patriarchy as a negative reference of the conception of what it is to be a man is in force in the media of moralistic groups that assume political and religious powers. Patriarchy is understood as an ideological system that constitutes male domination over women and society. Man is the holder of power, while women cannot exercise it, with only the role of procreator as a divine mission and caretaker of the home, until their sexuality was controlled by their spouses. Lenner (2019) invites us to reflect that this system only takes effect because some women support it by the conditions imposed.

The patriarchy system can only work with the cooperation of women. This cooperation is ensured by various means: gender indoctrination, educational lack, denial to women of the knowledge of their own history, division of women by the definition of "respectability" and "deviation" according to their sexual activities; restrictions and total coertion; through discrimination in access to economic resources and political power and by granting class privileges to women who obey. (LENNER, 2019, p.267).

By understanding the patriarchal system, and in the fact that feminist and LGBT movements played an important role in discussions about masculinities in contemporary times, it is admitted to avoid reflecting on what it is to be a male.

To claim that no one is born a man, becomes a man, this implies that being a woman and being a man is a social construction. Mead (2001) states that male and female behaviors cannot be explained as a natural and biological predisposition, but as a social construction that establishes rules and norms preserved and transmitted to the present by culture. And this social construction of masculinities manifests itself even before the individual is born, when the parents determine a color, present with toys and adorn the room with objects and colors that according to their conception are masculine. Banditer (1997), states that, what defines the human male, is not only male sexual organs, nor $\mathrm{Y}$ chromosome. Commonly, since childhood, adolescence and already adult man hears the expressions: Be male!, Act like male!, Prove that it is male!; It is an almost neurotic determinism on the part of the institutions, the subject has to prove to himself and to society that he is a man, that's getting sick! To be a man is to enter a perenal battle. The author also states that masculinity is marked by "not being".

Being a man means not being feminine; not being homosexual; means not being docile, dependent or submissive; not be feminised in physical appearance or gestures; not having sex or very intimate relations with other men; not be powerless with women. (BANDITER, 1997, p. 117).

Social roles are defined and imposed to follow a model of masculinity that in the patriarchy's view should not show affection, because it is a role considered feminine. The boy or boy feels obliged to fulfill the established and determined social roles, even if it is painful to him, in the face of this they are called to reject sensitivity, affection and ability to recognize vulnerability. Reflecting on this, Saffioti (1987) states that many men, in the name of these rules, of these impositions had to swallow their tears in moments of great sadness, anguish or mourning.

Sexist culture can be found in everyday life, such as in TV shows, newspapers, conversations with relatives and or 
friends, music and also women considered sexists. It is known to many that sexism affects women and in an unfortunate way are the main victims, leading them to disturbances of physical and psychological orders. Nevertheless, it is opportune to reflect on the cultural production imposed by the sexism that makes men victims, leading to psychic illnesses due to the prevailing social charges of structural sexism. Obviously, there is no intention here to compare pain, each person feels them subjectively, but think and reflect on how human existence would be much better without sexism.

Not understanding sexist man has an obligation to be man, and this implies several rigid behaviors and that over time become automatic. When it is said that they are also victims of sexism one should consider the male social roles established from child to present, as the male body must be built to be recognized and affirmed. Since his generation in the womb, culture has been demarcating as a must to be a man. The man is a victim of sexism when being tolhido in games, in the way of dressing, of acting, of the profession he chooses, if he does not want to be a father, if he does not want to marry, if he does not compact with games where women are coisified, if they are not sexually potent, to date early to show to family and friends, to have sex prematurely, to seek marriage, to have children and to encourage them to be men. When dealing with these social charges, masculinity is invited to silence their pains, to think of silence is to promote a space of not questioning this routine.

Not choosing what your manhood will be like is a movement that men face. The power of freedom, and the choice of fighting to break these paradigms is not an attribute of all, Nolasco (2006) states that freedom to be is an achievement that heterosexual or homosexual men do not have. In this way many lose their lives either because they can not stand the social pressure of how to be a real man, and opt for suicide, or because of their authoritarian behavior and with little capacity to dialogue are victims of homicide, in addition, involvement with alcohol and other drugs can be highlighted. For some, these are the outputs found to ease or silence pain. Silence presents marks on the subjectivity of the human being who imprisons speaking. Not verbalizing feelings and emotions can imply anxious symptoms, depressants, mood swings and addictions that impair male mental health.

However, as they are not accustomed to express ing their way, in view of the idea imposed on them that this act is feminine, they refuse to recognize that they are suffering and that they need help to deal with all internal movement. They prefer to omit and assume the macho, however, when they are alone they dream of a hug to welcome free of shame. Certainly, this suffering harms their own well-being and consequently the well-being of their families and peers, by understanding that it is a social involvement. It is this internal movement that leads them to feel anguish, fear and sadness, which can be named as loneliness, evidently not that loneliness that is manifested by the absence of people. Society does not want to deal with the pain and loneliness of man, they prefer to silence them and maintain the appearance that everything is fine with the increasing studies on masculinities and the groups of living aimed exclusively at men, giving them a space of speech, allowing them to reflect on the roles imposed by society, family and religion. These groups are spaces of care. Men, when allowed to attend these spaces, whether they are face-toface or virtual, give themselves the opportunity to know themselves, to verbalize what they feel, to cry, to exchange affections, to be vulnerable, obviously what goal is to bring this openness to the day to day.

The search for male care is part of the recognition that sexism is also harmful to them, whether heterosexual, bisexual, homosexual or trans men and any form of expression of the experience of masculinities, which is possible to deconstruct the roles imposed and rebuild masculinities living them healthily.

\section{Conclusions}

Understanding the males of our species is also to understand all cultural construction that emerges from the policy of regulating bodies from the colonization of patriarchy, involving the participation of social, feminist and LGBT movements to imply the new understandings of the masculine being, which comes from a singular to plural look, emerging masculinities. Masculinities are born from becomes man, by social construction, involving roles that are filed for this category, marking his body and controlling it, so the need to talk about this subject is to promote spaces for reflection and liberation of bodies, because silence is one of the behaviors taken with masculine and reinforced, since he is an implicatory in his mental health, developing symptoms that harm so.

In this reflection the importance of speaking and recognizing affections as promising quality of life, promoting spaces to recognize their limitations and pains or the need to question the male being, because this action impairs the development of the category.

\section{Acknowledgements}

I thank all the people who add to their experiences to my life, including my family, my friends, my Profrssors and my masters and undergraduate advisors! Gratitude!

\section{References}

[1] BADINTER, Elisabeth. XY: sobre a identidade masculina. 2. ed. Rio de Janeiro: Nova Fronteira, 1993.

[2] COUTO, Aline Guimarães; DITTRICH, Alexandre. Feminismo e análise do comportamento: caminhos para o diálogo. Perspectivas, São Paulo, v. 8, n. 2,p. 147-158, 2017. Disponível

em $<$ http://pepsic.bvsalud.org/scielo.php?script=sci_arttext\&pid= $\mathrm{S} 2177-35482017000200001 \& \operatorname{lng}=\mathrm{pt} \& \mathrm{nrm}=\mathrm{iso}>$. acesso em 14 jul. 2020. http://dx.doi.org/10.18761/PAC.2016.047.

[3] GOMÁRIZ, Enrique. "Los estudios de género y sus fuentes epistemológicas: periodización $\mathbf{y}$ perspectivas". In: RODRÍGUES, Regina (Ed.). Fin de siglo: genero y cambio civilizatorio. Santiago: Isis International, 1992. p. 83-110. 
(Ediciones de las Mujeres, n. 17).

[4] LENNER, Gerda. A criação do Patriarcado: histórias da opressão das mulheres pelos homens. São Paulo: Cultrix, 2019.

[5] MEAD, Margaret. Sex and temperament in three primitive societies, New York, William Morrow and c. 1935 (Trad. Bras. Rosa R. Krausz. São Paulo, Perspectiva)

[6] MEDRADO, Benedito; LYRA, Jorge. Por uma matriz feminista de gênero para os estudos sobre homens e masculinidades. Rev. Estud. Fem. Florianópolis, v. 16, n. 3, p. 809-840, dez. 2008. Disponível em $<$ http://www.scielo.br/scielo.php?script=sci arttext\&pid=S01 04-026X2008000300005\&lng=pt\&nrm=iso $>$. acessos em 14 jul.2020.http://dx.doi.org/10.1590/S0104026X2008000300005.

[7] NOLASCO, Sócrates A. O primeiro sexo e outras mentiras sobre o segundo: as questões que mais estão mexendo com a cabeça dos homens. Rio de Janeiro: BestSeller, 2006.

[8] NOLASCO, Sócrates A. O mito da masculinidade. Rio de Janeiro: Rocco, 1993.

[9] SAFFIOTI, H. O poder do macho. São Paulo: Moderna,1987. 